\title{
Activities of selected digestive enzymes during larval development of large yellow croaker (Pseudosciaena crocea)
}

\author{
Hongming $\mathrm{Ma}^{\mathrm{a}}$, Chantal Cahu ${ }^{\mathrm{b}}$, José Zambonino ${ }^{\mathrm{b}}$, Hairui $\mathrm{Yu}^{\mathrm{a}}$, Qingyuan Duan ${ }^{\mathrm{a}}$, \\ Marie-Madeleine Le Gall ${ }^{\mathrm{b}}$ and Kangsen Mai ${ }^{\mathrm{a}, *}$
}

a: The Key laboratory of Mariculture (Ministry of Education), Ocean University of China, Qingdao 266003, PR China

b: Laboratory of Fish Nutrition IFREMER-INRA, BP 70, 29280 Plouzané, France

*: Corresponding author : Tel.: +86 532 2032495; fax: +86 5322032495

\begin{abstract}
:
Large yellow croaker is an important marine fish species for aquaculture in China. Larval rearing of this species is still based on live prey feeding. The aim of this study was to describe the onset and development of the main digestive enzymes during larval development of this species, in order to obtain essential data for the formulation of a compound diet adapted to larvae. Enzymatic assays were conducted from day 1 post hatching to day 40 in larvae fed the following live prey sequence: rotifers, Artemia nauplii, copepods, and then frozen copepods. Assays were done on whole larvae until day 19, then on dissected larvae and on purified brush border membranes of intestine. Pancreatic enzymes, amylase, and trypsin, showed high activities from early stages, even before mouth opening. Mechanisms of pancreatic secretion were achieved from day 19. Enzymes of brush border membranes, alkaline phosphatase, and aminopeptidase $\mathrm{N}$, increased abruptly between day 23 and 25 , showing maturation of the intestinal digestive process. These data, together with data describing mouth enlargement during development, suggest that large yellow croaker larvae could be fed successfully with a compound diet from early stages, at least from day 23.
\end{abstract}

Keywords: Alkaline phosphatase; Aminopeptidase N; Amylase; Fish larval development; Pseudosciaena crocea; Trypsin 


\section{Introduction}

Yellow croaker (Pseudociana crocea) is an economically important species in south China with long catching history. The natural resource was nearly depleted due to excessive catching up to 1980 's. Farming of yellow croaker boomed after success in larvae culture since late 1980s (Lin et al, 1991). The fingerling production reaches more than 300 million juveniles in Fujian province, the major area of yellow croaker culture (Zhang et al., 2001). Until now, the rearing of yellow croaker larvae and juveniles still depends totally on live preys, which account for more than $70 \%$ of total cost for 40 days old juvenile. Poor growth is always observed at late juvenile stage fed live prey. Moreover, the supply and nutritional value of live preys are usually instable due to climate or environment variations (Kolkovski, 2001). This problem constitutes the biggest limiting factor to the production of yellow croaker fingerlings. It is therefore urgent to develop a compound diet sustaining the growth of yellow croaker larvae and juveniles in substitution to live preys.

Many researches have been conducted in the last two decades to study the digestive ability and specific nutritional requirements of fish larvae and juveniles (Cahu and Zambonino Infante, 2001). Ontogenesis of digestive enzymes and developmental features of digest tract have been well documented in several species, such as sea bass (Zambonino Infante and Cahu, 1994), sole (Ribeiro et al., 1999), red drum (Buchet et al, 2000), Japanese flounder (Kurokawa and Suzuki 1996, 1998) and turbot (Hoehne-Reitan et al., 2001). A maturation process of digestive tract occurs some weeks after hatching in fish larvae and corresponds to the switch from larval to adult mode of digestion (Zambonino Infante and Cahu, 2001). The achievement of fingerling relies on a proper development of digestive functions during larval life, and the maturation process of digestive tract can be altered by the diet composition. Attempts were conducted to substitute partially or completely compound diets for live prey in larval stage (Cahu et al. 1998; Yúfera et al., 1999). Recent results showed that total substitution of live prey by compound diet led to proper development and good 
growth and survival in sea bass reared in laboratory (Cahu et al., 2003) and can be considered at commercial scale.

The aim of this study was to describe the onset and development of the main digestive enzymes in yellow croaker fed the classical live prey sequence, to provide data on the digestive features of yellow croaker in larvae and juveniles (from hatchery to 40 days after hatching), which will be useful for formulating a compound diet for the larval stages of this species.

\section{Materials and methods}

\subsection{Animals and live preys}

The parental fish of yellow croaker (Pseudosciaena crocea) were 2 years old male and female with body weight of $0.5 \sim 0.8 \mathrm{~kg}$ and $0.75 \sim 1 \mathrm{~kg}$ respectively. Artificial induced spawning was conducted at $20-21.5^{\circ} \mathrm{C}$. Eggs hatched for 31 hours after spawning. Larvae were then reared in $8 \times 4 \times 1.5 \mathrm{~m}$ (length $\times$ width $\times$ height $)$ cement pool. Water level maintained at 1.3 meter high, the total water volume in the pool is 41.6 cube meters. The initial stocking density was about 60 larvae $1^{-1}$, which decreased gradually to about $81^{-1}$ at D23 when the total length reached $1 \mathrm{~cm}, 5$ larvae $1^{-1}$ at D30; 3 larvae $1^{-1}$ at D40 due to the high elimination ratio. The larvae were reared in seawater with salinity of 27-28 $\mathrm{g} \mathrm{l}^{-1}$, which had been filtered through two sand filters and a cloth filter before use. From D4 to D20, $2 \sim 3 \times 10^{7} 1^{-1}$ of chlorella was also cultured in the water to adjust the $\mathrm{pH}$ and color of the water. The temperature was kept at $23-25^{\circ} \mathrm{C}$ using steam-heated iron pipelines, which was stalled at the bottom of the pool. After D30, temperature was decreased gradually to $17^{\circ} \mathrm{C}$ at a rate of $1^{\circ} \mathrm{C}$ per day to make the larvae accustom to the temperature of the open sea. Optimal Oxygen level was maintained using air pump. Light intensity was 500-1500 lux at water surface. Water exchange began from D7 at a rate of $20 \%$ per day, which was slowly 
adjusted to $50 \%$ per day at D30. The bottom of the pool as well as the surface water was cleaned every morning.

Larvae were fed with rotifer from mouth opening (D4) to D20 (10000 to $150001^{-1} 1-4$ times per day), Artemia from D14 to D28 (1000-1500 $1^{-1}, 2-4$ times per day), live copepods, the dominant species of which was Calanus sinicus, from D21 to D30 (0.02-0.03 $\mathrm{g} \mathrm{l}^{-1}, 2-3$ times per day) and frozen copepods from D31 to D40 (0.03-0.04g $1^{-1}, 4-5$ times per day). The rotifer and Artemia were cultured with chlorella and yeast, and enriched with DHA and EPA microcapsule: 50DE (a product of Marine Culture Institute of Shandong Province, China) for 12 hours before use.

\subsection{Sampling and dissection}

Hundreds of larvae were sampled at predetermined intervals (1, 2, 3, 5, 7, 9, 11, 13, $15,17,19,21,23,25,30,35$, and 40 days after hatching) to monitor growth. Sampling was carried out every morning before food distribution. Body length of 30 larvae was measured each time. Wet weight of 3 groups (100 larvae per group) was measured after absorbing water with filter paper. Mouth width (gape) was measured under stereomicroscope with ocular micrometer.

Four samples of larvae were collected at days 1, 5, 9, 15, 21, 23, 25, 30, 35 and 40 for enzymatic analysis and were immediately frozen with liquid nitrogen and stored at $-80^{\circ} \mathrm{C}$. The larvae older than $\mathrm{D} 19$ were dissected as described by Cahu and Zambonino Infante (1994), in order to separate pancreatic and intestinal segments. Dissection was conducted under microscope on a glass plate maintained at $0^{\circ} \mathrm{C}$. Larvae younger than D19 are too small to dissect. They were treated as whole larvae.

Larvae of D40 as well as live preys, including rotifer, Artemia, live and frozen copepods, were collected and immediately frozen with liquid nitrogen and stored at $-80^{\circ} \mathrm{C}$ for further biochemical analysis.

\subsection{Analytical methods for enzymes}


For larvae younger than D19, $250 \mathrm{mg}$ of larvae were put into a clean tube and homogenized with vortex for $30 \mathrm{sec}$ then briefly centrifuged. The supernatant, which contained the secreted trypsin and amylase, was collected for further assays. The pellet was homogenized in $1.5 \mathrm{ml}$ cold water $\left(0^{\circ} \mathrm{C}\right)$ with an homogenizer (Polytron, PT-MR 2100) at maximum speed for $30 \mathrm{sec}$ then centrifuged at $3300 \mathrm{~g}$ for $3 \mathrm{~min}$. The supernatant was collected for the assays of pancreatic trypsin, amylase and total alkaline phosphatase (AP) and aminopeptidase N (AN) activity. For the dissected samples (D19 D40), 0.2-0.3 g pancreatic segments were homogenized in $2 \mathrm{ml}$ cold $\left(0^{\circ} \mathrm{C}\right)$ distilled water, centrifuged at $3300 \mathrm{~g}$ for $3 \mathrm{~min}$, supernatant was collected for further assay. Also 0.2-0.3 g intestinal segments were homogenized to purify brush border membranes (BBM) according to a method developed for intestinal scrapping (Crane et al., 1979) and adapted to intestinal segment (Cahu and Zambonino Infante , 1994). Before $\mathrm{CaCl}_{2}$ was added, $1 \mathrm{ml}$ homogenate was spared for intestinal enzymes assay. The spared homogenate was then centrifuged at $3300 \mathrm{~g}$ for $3 \mathrm{~min}$; supernatant was used for enzymes assay.

Trypsin and amylase activities were assayed according to Holm et al. (1988) and Métais and Bieth (1968) respectively. Aminopeptidase N (AN) and alkaline phosphatase (AP) were assayed in whole larvae (younger than D19) or both in intestinal segments and BBM in older larvae (D19 D40) according to Maroux et al. (1973) and Bessey et al. (1946) respectively. Assay of a cytosolic peptidase, leucine-alanine peptidase (leu-ala) was performed on intestinal homogenate using the method of Nicholson and Kim (1975). Enzyme activities were expressed as segmental activity (mU/ larva segment) and specific activity (mU/ mg protein). Protein was determined according to Bradford (1976).

Data on pancreatic enzymes i.e. amylase and trypsin were expressed as a ratio of segmental activity in intestine related to that in both pancreatic and intestinal segment (total amylase or trypsin content). This ratio reflects the secretion level of pancreatic enzymes (Zambonino Infante et al., 1996). The ratio of enzyme activity of AP in 
$\mathrm{BBM}$ related to leu-ala peptidase activity was calculated using the segmental activities, i.e. the total activity of each enzyme in intestinal segment.

\subsection{Body composition and live prey composition}

The samples for body composition and live prey composition test were freeze-dried. Dry matter, ash, crude protein, and lipid were determined according to established methods (AOAC, 1990). The methods to determine glycogen were modified from Reddi and Jyothirmayi (1992) and Chun and Yin (1998). Briefly, freeze-dried live prey samples $0.5 \mathrm{~g}$ was dissolved in $2 \mathrm{ml} 20 \% \mathrm{KOH}$ at $100^{\circ} \mathrm{C}$ for $20 \mathrm{~min}$. After the solution was cooled down to room temperature, diluted 500 times with distilled water. The diluted solution $1 \mathrm{ml}\left(0^{\circ} \mathrm{C}\right)$ was mixed with $3 \mathrm{ml}$ of $0.2 \%$ anthrone and kept at $100^{\circ} \mathrm{C}$ for $10 \mathrm{~min}$, then cooled to room temperature and assayed by absorbance at 620 nm.

\subsection{Statistical analysis}

Results are given as mean \pm S.D ( $n=4$ for enzymes; $n=3$ for body weight of 100 larvae; $\mathrm{n}=30$ for body length). Data on ratio of segmental activities were $\arcsin \left(\mathrm{X}^{1 / 2}\right)$ transformed. The variance homogeneity of the data was checked using Bartlett's test (Dagnelie, 1975). Data were compared by one-way ANOVA followed by Newman-Keuls multiple range test when significant differences were found at the $\alpha=$ 0.05 level.

\section{Results}

\subsection{Growth and mouth width}

The growth of yellow croaker larvae is presented as body length per larvae and body weight (wet) per 100 larvae related to days after hatching (Figure 1). The curves of both body length and body weight were S-shaped, showing a period of rapid growth from D21 to D35. The growth before D21 was remarkably slow, and slowed down again after D35. This trend was more manifest in body weight than in body length. 
The mouth width (gape) increased during development and reached more than $2 \mathrm{~mm}$ in 40-day-old larvae (Figure 1). The relationship between mouth width (MW) and body length (BL) was linear (Figure 2):

$\mathrm{MW}=0.1471 \mathrm{TL}-0.2487\left(\mathrm{R}^{2}=0.9844\right)$

while mouth width increased exponentially with body weight:

$\mathrm{MW}=1.2872 \mathrm{BW}^{0.5674} \quad\left(\mathrm{R}^{2}=0.9775\right)$.

\subsection{Body composition and live prey composition}

Biochemical composition of the live preys was different (Table 1): rotifer and live copepods exhibited a high level in protein, more than $50 \%$ of total dry weight, compared to Artemia. Lipid content was higher in rotifer than in Artemia and live copepods. Live copepods had the same content in glycogen as Artemia. Biochemical composition of frozen copepod was quite different compared to live preys. Protein and lipid content was significantly lower, whereas ash content represented more than one third of the total dry matter. The glycogen content was relatively high in frozen copepods, more than $7 \%$ of total dry matter. Composition of fish larvae was close to that of live copepods.

\subsection{Pancreatic enzymes}

Specific activities of the two pancreatic enzymes assayed are presented in Figure 3. Both trypsin and amylase were present in yellow croaker larvae at D1, before mouth opening. Specific activity of trypsin decreased gradually from D5 to D25. After this date, specific activity of trypsin maintained at similar low level up to D40. Specific activity of amylase followed globally a similar pattern: high level up to D15, then decease up to D25. Afterward, amylase level increased from D30 toD40.

The ratio "pancreatic enzyme in intestinal segment / pancreatic enzyme in whole larvae", expressed in percentage, illustrated the secretion (Figure 4). This ratio was 
less than $30 \%$ for trypsin in young larvae and increased up to $50 \%$ as early as D21. The ratio was around $40 \%$ for amylase in early stages and reached $80 \%$ from D21.

\subsection{Intestinal enzymes}

The activities of the intestinal enzymes, AN and AP, assayed in intestine homogenate and in purified BBM of intestine are presented in Figure 5. Before D21, it was not possible to purify the brush border membranes. The activity AP and AN, related to protein concentration of intestine, remained at low values during larval development. $\mathrm{AN}$ and AP activity in purified BBM showed a 3 folds increase from D21 to D40. Particularly, AP activity abruptly increased from D21 to D25 and reached a plateau until D40. The purification factor was 5 to 8 for the two enzymes, i.e., enzymatic activity was 5 to 8 times higher in purified membranes than in homogenates.

The ratio of $\mathrm{AN}$ or $\mathrm{AP}$ segmental activity in $\mathrm{BBM}$ related to a cytosolic enzyme leu-ala peptidase (X 1000) are presented in table 2. The AP/leu-ala ratio abruptly increased between D23 and D25. It was 5 to 7 times higher in old stages than in young stages. The ratio AN/leu-ala increased slighter from D23 to D30, and was 4 folds higher at D40 than at D21.

\section{Discussion}

During this experiment, the growth of yellow croaker larva exhibited a pattern similar to that of other farmed marine fish species, in particular European sea bass (Zambonino Infante and Cahu, 1994). Indeed, the growth was slow at the beginning of the life, up to D15-20, then dramatically accelerated up to D30. Nevertheless, the S-shape in body weight and length revealed a depressed growth from day 30 onwards, suggesting that some of the rearing parameters were limiting. It can be assumed that the decreasing temperature, $23^{\circ} \mathrm{C}$ at $\mathrm{D} 30$ to $17^{\circ} \mathrm{C}$ at $\mathrm{D} 36$, contributed to depress growth during the final step of the larval rearing. The feeding sequence used in this larval rearing until day 30 was usual for larval rearing in hatchery (Person-Le Ruyet et 
al., 1993). The rotifers, Artemia, and live copepods had a high protein and lipid level, supporting good larval growth, but the composition of frozen copepods was quite different: the low level in protein and mainly in lipid, associated to the high ash concentration led to a poor dietary value of this diet. Nutrients were probably lost during freezing and mainly thawing.

The increase of mouth size was proportional to body weight and body length increase. A same linear relationship between mouth width and body length was described in another marine fish species, Sparus aurata (Fernandez-Diaz et al., 1994). The authors associated the ability of this species to be fed on compound diet during early stages to the mouth size. Compared to sea bream, it appeared that yellow croaker has a mouth 1.6 times larger, suggesting that the Chinese species is a good candidate for early weaning with compound diet. The available technology allows adapting the microparticle size to the mouth width, starting from $50 \mu \mathrm{m}$ (Cahu and Zambonino Infante, 1994, Fernandez-Diaz and Yufera, 1995, Yufera et al., 1999). Beside convenient technology, knowledge on nutritional requirements in yellow croaker is needed to formulate suitable compound for this species. Moreover, the study of the digestive specificities of early stages will be of great help to adapt the nutrient nature and its form of supply in microdiet. Indeed, it has been demonstrated that digestive tract and digestion process undergo major developmental changes during the first weeks of life in marine fish (Ferraris et al., 1987, Buddington and Diamond, 1989) and the microparticulated diets might be formulated taking into account the capacity of larvae to digest this diet (Cahu and Zambonino Infante, 2001).

During the present experiment, larvae were fed live preys, which can be considered as a natural feeding, allowing proper development. This developmental process, and particularly for the digestive functions, can be considered as a reference to evaluate the effect of a formulated microdiet feeding on larvae. Two main steps are considered as crucial in the maturation process of the digestive function in fish larvae. They were described in Dicentrarchus labrax (Cahu and Zambonino Infante, 1995), in Solea 
senegalensis (Ribeiro et al., 1999), Scianops ocellatus (Buchet et al., 2000, Lazo et al., 2000) Paralichthys olivaceus (Kurokawa and Suzuki, 1996, 1998). The achievement of pancreas secretion function constitutes the first step, and the second is the onset of brush border membrane enzymes in intestine. In this study, the general pattern of pancreatic enzyme activity during development was similar to that already described in other species (Buddington, 1985). The specific activities were very high during the first two of life, then a decline occurred. This decrease in specific activities was due to an increase of body protein (as specific activity is the ratio activity per mg protein) and does not reflect a lowering in digestive capacity. It can be pointed out that yellow croaker larvae exhibited high trypsin and high amylase activities during endogenous life (before mouth opening), indicating a large potential to synthesise enzymes, even without diet stimulation as it has been shown in other species, as Clupea harengus (Pedersen et al., 1987). The increase in amylase activity from day 30 can be attributed to the high level in glycogen in frozen copepods distributed to larvae from this date. Indeed, amylase is stimulated by glycolytic chains, glycogen and starch in fish larvae (Péres et al., 1998).

The proportion of secreted pancreatic enzymes increased abruptly after the second week of life, showing a strengthening of secretion process, which normally occurs chronologically after the onset of enzyme synthesis during fish development (Zambonino Infante and Cahu, 2001). It appeared that the process of pancreatic secretion is achieved around D20. The secretion level at this date can be considered as a reference for this species to study the effect of a formulated diet. Indeed, the nature and level of dietary nutrient may interfere with the maturation process of digestive tract. A diet containing an inadequate supply of protein would prevent the strengthening of secretion process as it has been shown in sea bass (Cahu and Zambonino Infante, 1995).

The purification of brush border membrane of enterocytes was efficient, as the yield factor was 5 to 8 (Crane et al., 1979). This validates the observations made in this 
study in enzyme activities of brush border membrane. The intestinal enzymes AP and AN showed an abrupt increase from D20. The ratio AP/leu-ala and AN/leu-ala showed an increase of the digestion at the level of membranes, when the cytosolic digestion decreased between D23 and D25. This process reflected the switch from a primary to an adult mode of digestion. The maturation process of enterocyte has been extensively described in mammals (Henning, 1987) and more recently in fish (Zambonino Infante and Cahu, 2001) and occurs in a short window of time. A proper achievement of this process determines the larval survival (Cahu and Zambonino, 1995).

This study showed that the classical live prey feeding sequence commonly used in hatchery for many species allows also a proper development in yellow croaker larvae. Nevertheless, it appeared that the biochemical composition of live prey is variable. Moreover, live prey as Artemia are expensive, and copepods are not available in large amount all over the year. This problem is particularly sensitive with old larvae, which consume a large amount of food. The preys must be stocked to overcome problems of supply and cost, but their composition is negatively altered when frozen. In this case a compound diet will better meet the nutritional requirements, will be less expensive, and will contribute to preserve the wild stock of zooplankton.

This study presents the first data on digestive functions in yellow croaker larvae and constitutes a first step in the development of a compound diet for the larvae of this species. It shows in particular that a weaning around day 25 should be considered as yellow croaker larvae have achieved at this date the maturation of their digestive functions.

\section{Acknowledgements}

This work was supported by the project "Nutrition and weaning diet studies on marine 
fish larvae" sponsored by Educational Ministry of China. Sino-France cooperation project (PRA BT 01-03) supported a part of the cost and promoted the cooperation between Chinese and French scientists. 


\section{References}

AOAC, 1990. In: Helrich, K. (Ed.), Official Methods of Analysis, 15th ed. Association of Official Analytical Chemists, Arlington, VA.

Bessey, O.A., Lowry, O.H., Brock, M.J., 1946. Rapid coloric method for determination of alkaline phosphatase in five cubic millimeters of serum. J. Biol. Chem. 164, 321-329.

Bradford, M.M., 1976. A rapid and sensitive method for the quantitation of microgram quantities of protein utilizing the principle of protein-dye binding. Anal. Biochem. 72, 248-254.

Buchet, V., Zambonino Infante, J.L., Cahu, C.L., 2000. Effect of lipid level in a compound diet on the development of red drum Sciaenops ocellatus larvae. Aquaculture 184, 339-347.

Buddington, R., 1985. Digestive secretion of lake sturgeon, Acipenser fulvencens, during early development. J. Fish Biol. 26, 715-723.

Buddington, R.K., Diamond J.M., 1989. Ontogenic development of intestinal transporters. Am. Rev. Physiol. 51, 601-619.

Cahu, C., Zambonino Infante, J.L., 1994. Early weaning of sea bass Dicentrarchus labrax larvae with a compound diet: effect on digestive enzymes. Comp. Biochem. Physiol. 109A, 213-222.

Cahu, C., Zambonino Infante, J.L., 1995. Maturation of the pancreatic and intestinal digestive functions in sea bass (Dicentrarchus labrax): effect of weaning with different protein sources. Fish Physiol. Biochem., 14: 431-437.

Cahu, C., Zambonino-Infante, J.L., Escaffre, A.M., Bergot, P., Kaushik, S., 1998. Preliminary results on sea bass Dicentrarchus labrax larvae rearing with compound diet from first feeding, comparison with carp Cyprinus carpio larvae. Aquaculture 169, 1-7.

Cahu, C., Zambonino Infante, J.L., 2001. Substitution of live food by formulated diets in marine fish larvae. Aquaculture 200, 161-180.

Cahu, C., Zambonino Infante, J.L. and Barbosa, V., 2003. Effect of dietary 
phospholipid level and phospholipid:neutral lipid value on the development of sea bass (Dicentrarchus labrax) larvae fed a compound diet. Br. J. Nutr. 90, 21-28.

Chun, Y., Yin, Z.D.,1998. Glycogen assay for diagnosis of female genital Chlamydia trachomatis infection. J. Clin. Microbiol. 36, 1081-1082.

Crane, R.K., Boge, G., Rigal, A., 1979. Isolation of brush border membranes in vesicular form from the intestinal spiral valve of the small dogfish Scyliorhinus canicula . Biochim. Biophys. Acta 554, 264-267.

Dagnelie, P., 1975. Les methodes de l'inference statistique. In: Ducolot, J. Ed. , Theorie et Methodes Statistiques, Vol. 2. Les Presses Agronomiques de Gembloux, Gembloux, Belgium, pp. 1-463.

Fernández-Díaz, C., Pascual, E., Yúfera, M., 1994. Feeding behaviour and prey size selection of gilthead seabream, Sparus aurata, larvae fed on inert and live food. Mar. Biol. 118, 323-328.

Fernandez-Diaz C., Yufera M., 1995. Capacity of gilthead seabream Sparus aurata L. Larvae to break down dietary microcapsules. Aquaculture 134, 269-278.

Ferraris, R.T., Tan G.D., De La Cruz, M.C., 1987. Development of digestive tract of milkfish Chanos chanos (Forskal): histology and histochemistry. Aquaculture 61, 241-257.

Kolkovski, S., 2001. Digestive enzymes in fish larvae and juveniles-implications and applications to formulated diets. Aquaculture 200,181-201.

Hoehne-Reitan, K., Kjorsvik, E., Gjellesvik, D.R., 2001. Development of bile salt-dependent lipase in larval turbot. J. Fish Biol. 58, 737-745.

Kurokawa, T., Suzuki, T., 1996. Formation of the diffuse pancreas and the development of digestive enzyme synthesis in larvae of the Japanese flounder Paralichthys olivaceus. Aquaculture141,267-276.

Kurokawa, T., Suzuki, T., 1998. Development of intestinal brush border aminopeptidase in the larval Japanese flounder Paralichthys olivaceus. Aquaculture 162, 113-114.

Henning, S.J., 1987. Functional development of the gastrointestinal tract. In: Johnson, L.R. Ed. , Physiology of Gastrointestinal Tract. Raven Press, New York, pp. 
$285-300$.

Holm, H., Hanssen, L.E., Krogdahl, A., Florholmen, J., 1988. High and low inhibitor soybean meals affect human duodenal proteinase activity differently: in vivo comparison with bovine serum albumin. J. Nutr.118, 515-520.

Lazo, J.P., Dinis, M.T., Holt, G.J., Faulk C., Arnold, R.A. 2000 Co-feeding microparticulate diets with algae: toward eliminating the need of zooplankton at first feeding in larval red drum (Sciaenops ocellatus). Aquaculture 188, 339-351.

Lin, D.J., Zhan, J., Zheng, Z.Y., Weng, Z.C., Shu, Y.Z., 1991. Studies on the artificial propagation of the large yellow croaker, Pseudosciaena crocea (Richardson). J. Fujian Normal Univ. 7,71-79. (in Chinese with English abstract)

Maroux, S., Louvard, D., Baratti, J., 1973. The aminopeptidase from hog-intestinal brush border. Biochim. Biophys. Acta 321, 282-295.

Métais, P., Bieth, J., 1968. Determination de 1'a-amylase par une microtechnique. Ann. Biol. Clin. 26, 133-142.

Nicholson, J.A., Kim, Y.S., 1975. A one-step L-amino acid oxidase assay for intestinal peptide hydrolase activity. Anal. Biochem. 63, 110-117.

Péres, A., Zambonino Infante, J.L., Cahu, C.L., 1998. Dietary regulation of activities and mRNA levels of trypsin and amylase in sea bass (Dicentrarchus labrax) larvae. Fish Physiol. Biochem. 19, 145-152.

Reddi, A.S., Jyothirmayi, G.N., 1992. Effect of chronic metformin treatment of hepatic and muscle glycogen metabolism in KK mice. Biochem. Med. Metab. Biol. 47,124-132.

Pedersen, B.H., Nilssen, E.M., Hjelmeland, K., 1987. Variation in the content of trypsin and trypsinogen in larval herring (Clupea harengus) digesting copepod nauplii. Mar. Biol. 94, 171-181.

Person-Le Ruyet, J., Alexandre, J.C., Thébaud, L. Mugnier C., 1993. Marine fish larvae feeding : formulated diets or live preys? J. World Aquac. Soc. 24, 211-224

Ribeiro, L., Zambonino Infante, J.L., Cahu, C., Dinis, M.T., 1999. Development of digestive enzymes in larvae of Solea senegalensis, Kaup 1858. Aquaculture 179, 465-473. 
Yufera, M., Fernandez-Diaz, C., Pascual, E., 1999. A highly efficient microencapsulated food for rearing early larvae of marine fish. Aquaculture 177, 249-256.

Zambonino Infante, J.L., Cahu, C.L., 1994a. Influence of diet on pepsin and some pancreatic enzymes in sea bass Dicentrarchus labrax larvae. Comp. Biochem. Physiol. 109A, 209-212.

Zambonino Infante, J.L., Cahu, C.L., 1994b. Development and response to a diet change of some digestive enzymes in sea bass Dicentrarchus labrax larvae. Fish Physiol. Biochem. 12, 399-408.

Zambonino Infante, J.L., Cahu, C.L., Peres, A., Quazuguel, P., Le Gall, M.M., 1996. Sea bass Dicentrarchus labrax fed different artemia rations: growth, pancreas enzymatic response and development of digestive functions. Aquaculture 139, $129-138$.

Zambonino Infante, J.L., Cahu, C.L., 2001. Ontogeny of the gastrointestinal tract of marine fish larvae. Comp. Biochem. Physiol.130C, 477-487

Zhang, Q.Y., Hong, W.S., Chen, P.X., 2001. Status and prospects of artificial propagation and breeding technique of marine fish in Fujian. J. Oceanography in Taiwan Strait. 20, 266-273. (in Chinese with English abstract) 


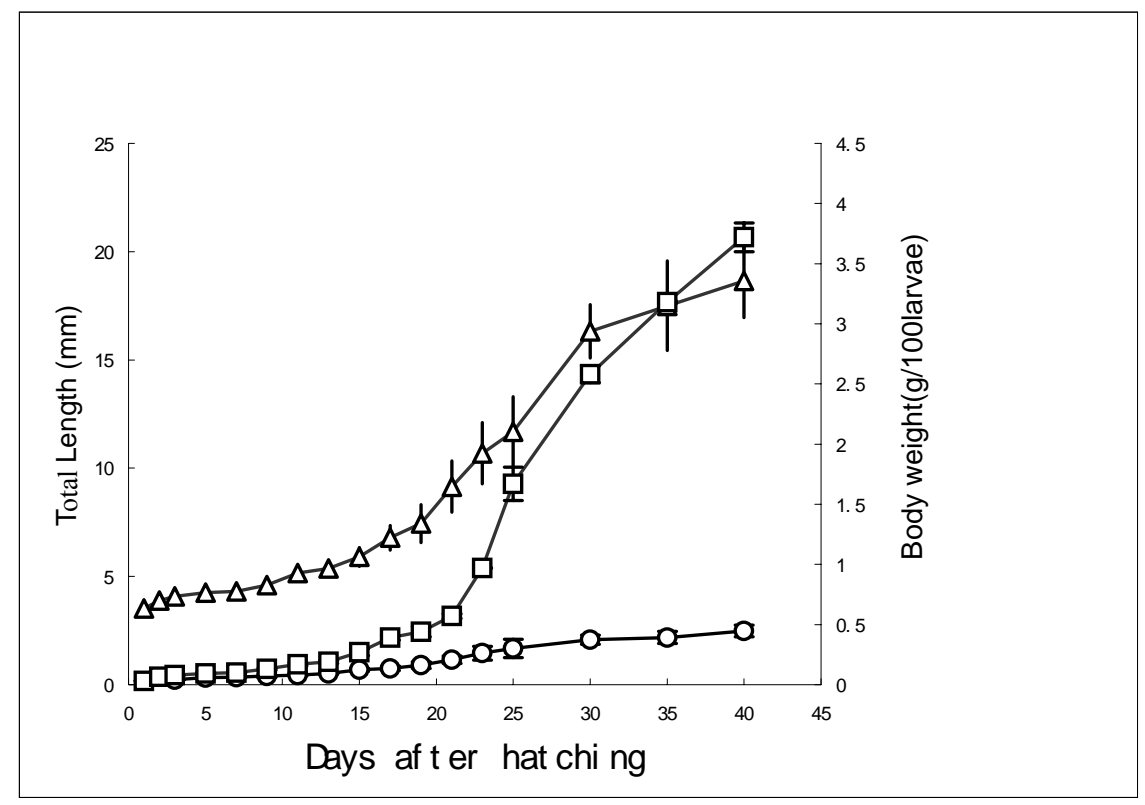

Figure 1 : Total length $(\triangle)$, body weight $(\diamond)$ and mouth width $(\circ)$ of P. crocea during larval and juvenile development related to days after hatching.

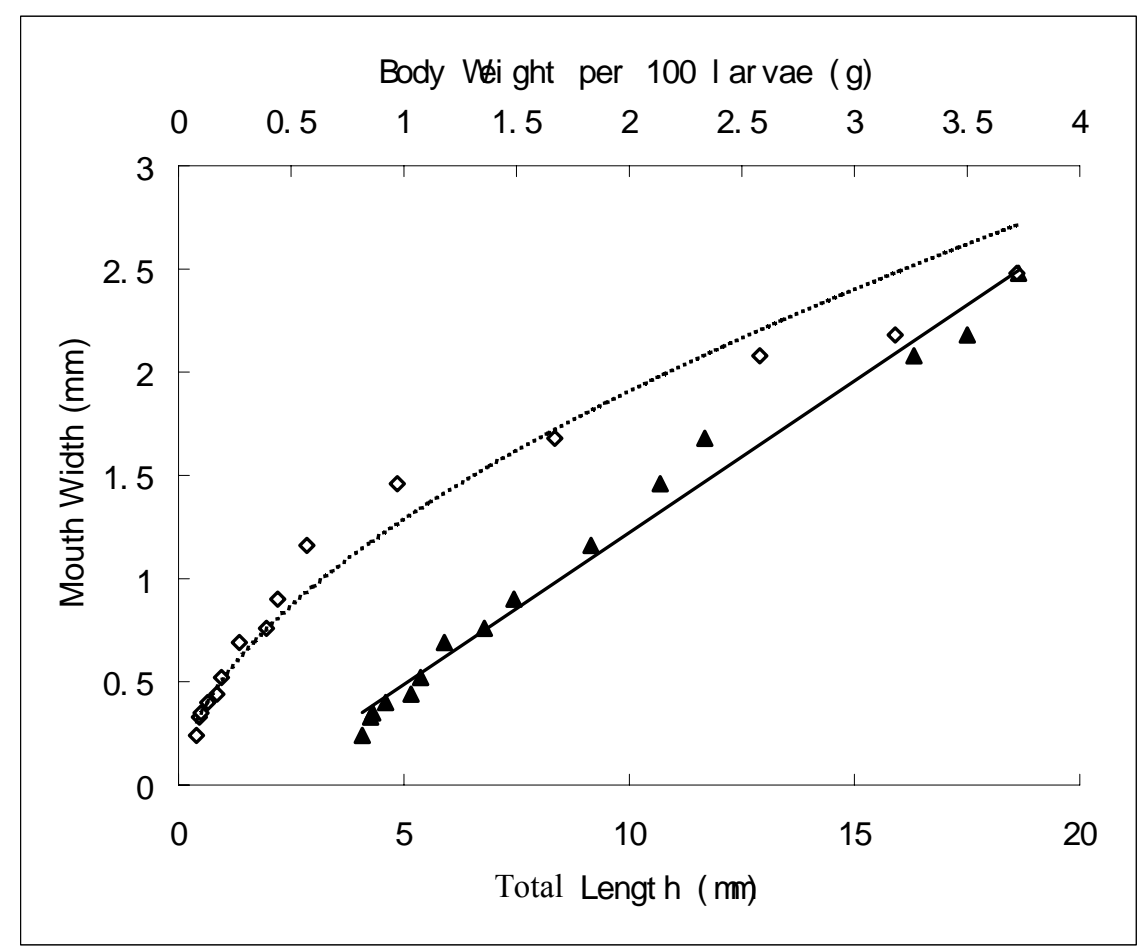

Figure 2 : Mouth width (gape) as a function of total length (continuous line) or body weight (100 larvae) (dashed line) in P crocea larvae. 

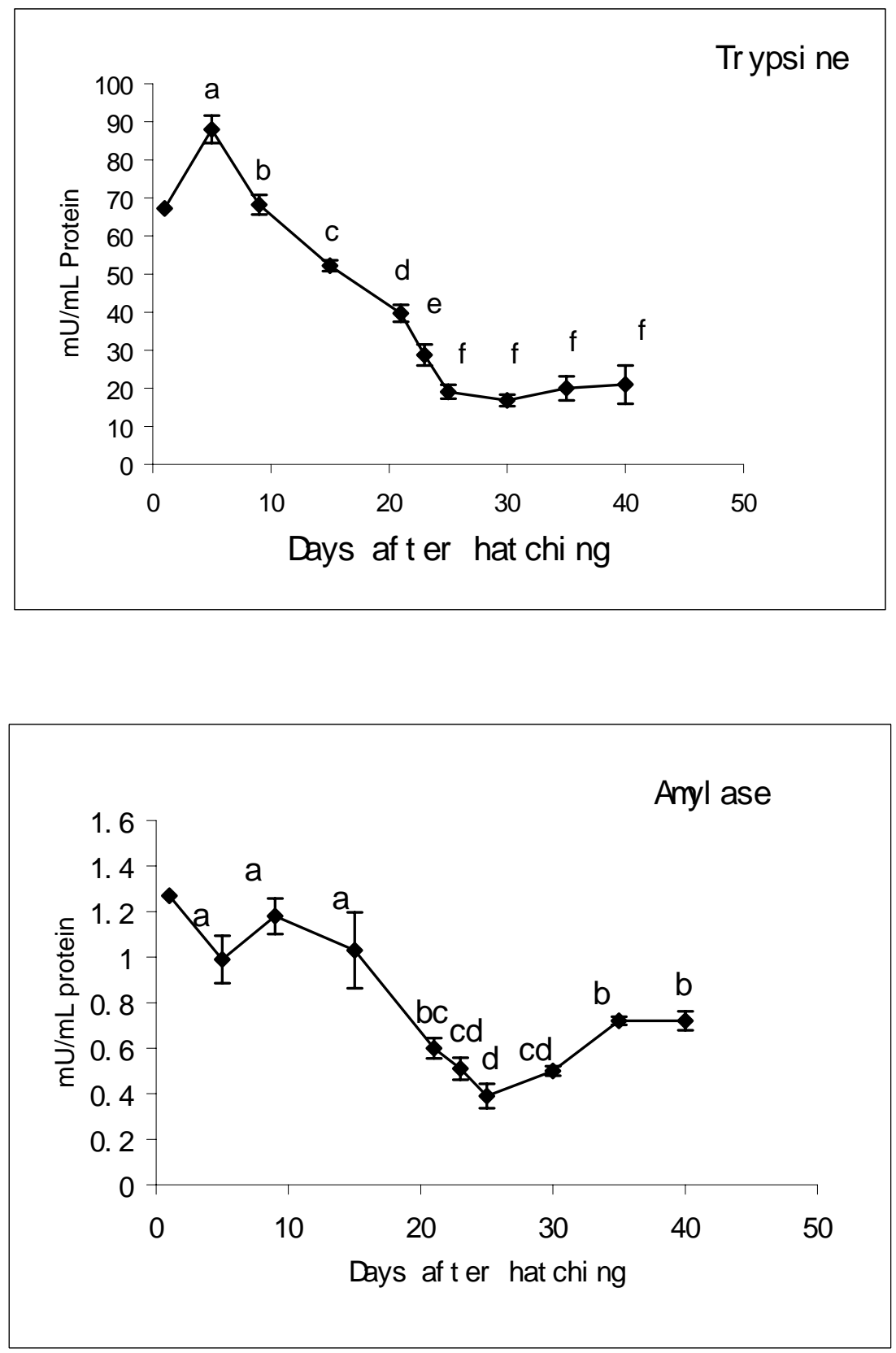

Figure 3: Specific activity of two pancreatic enzymes, amylase and trypsin, assayed in pancreas of $P$. crocea during larval and juvenile development. Means \pm SD $(n=4)$ with the same superscript letter are not significantly different $(P<0.05)$ 

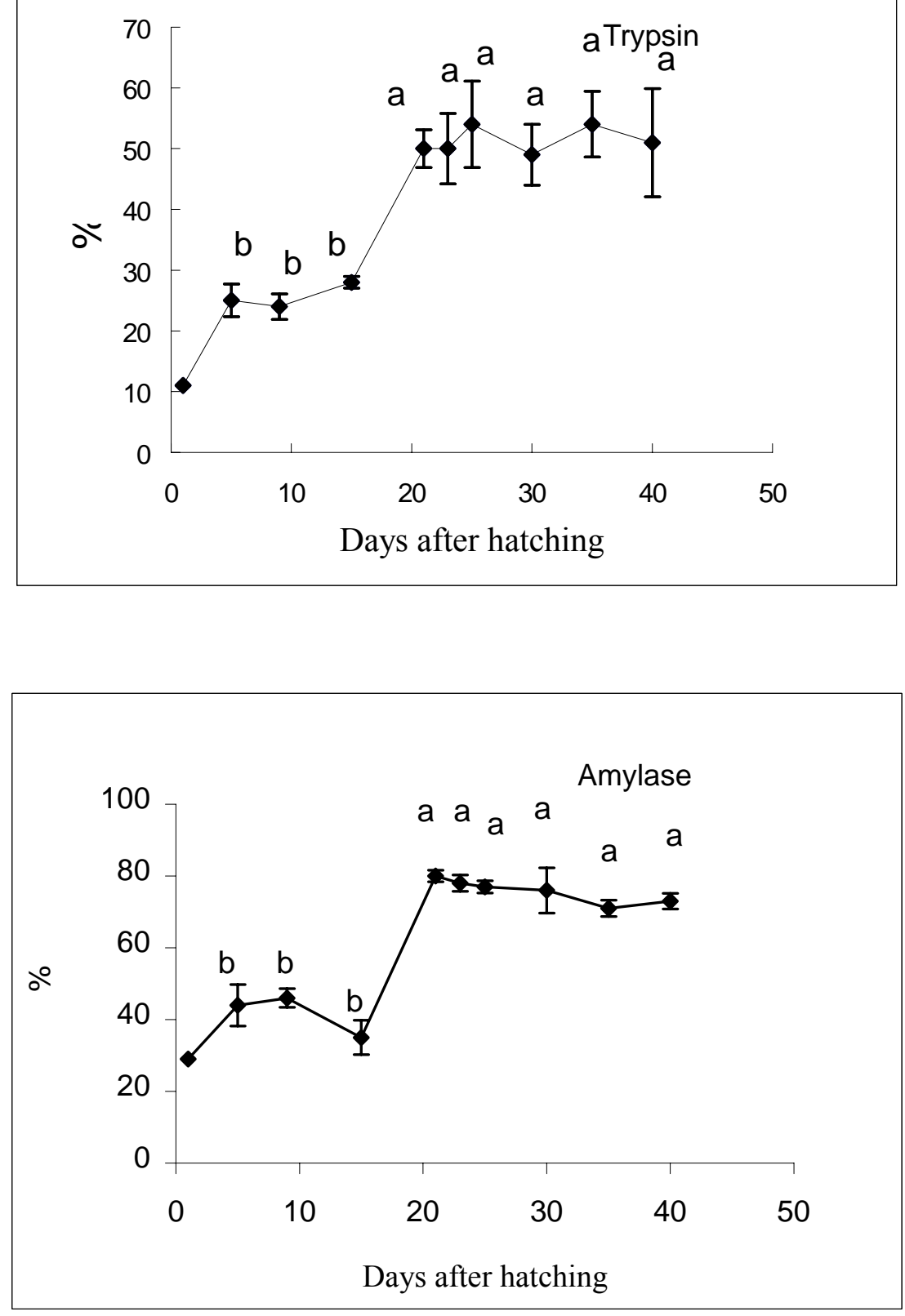

Figure 4 : Percentage of secreted trypsin and amylase (trypsin or amylase assayed in intestinal segment related to total trypsin or amylase) during larval and juvenile development of $P$. crocea. Means \pm SD $(n=4)$ with the same superscript letter are not significantly different $(P<0.05)$ 

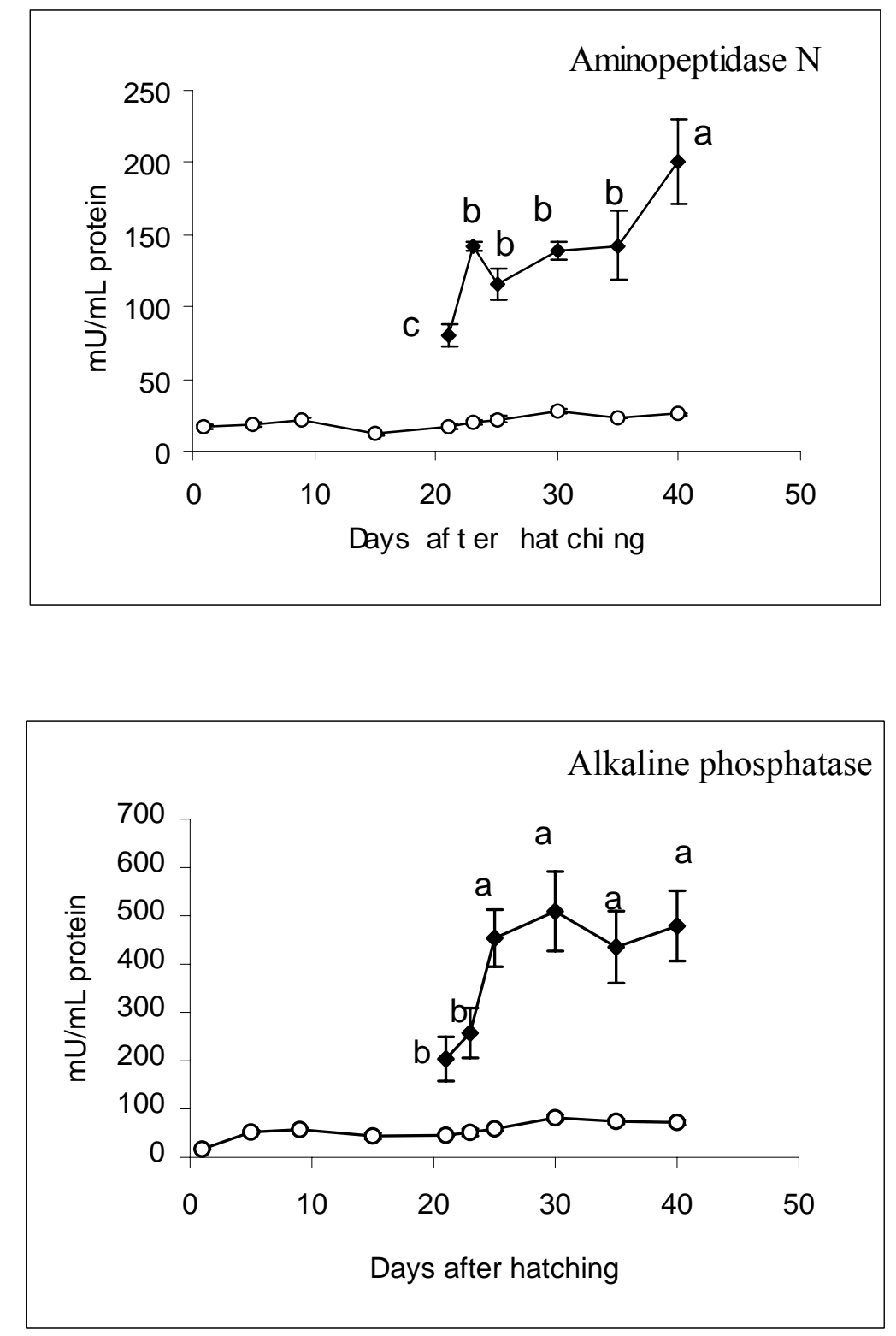

Figure 5: Specific activity of aminopeptidase $\mathrm{N}$ and alkaline phosphatase in intestinal segment homogenate $(\diamond)$ and in purified brush border membrane of intestine $(\diamond)$ during larval and juvenile development of $P$. crocea. Means $\pm \operatorname{SD}(n=4)$ with the same superscript letter are not significantly different $(P<0.05)$ 
Table 1. Biochemical composition of preys used in larval and juvenile rearing and body composition of yellow croaker at D40, related to total dry matter. Means $\pm \mathrm{SD}(\mathrm{n}=3)$ with the same superscript letter are not significantly different $(P<0.05)$

\begin{tabular}{llllll}
\hline & Rotifer & Artemia & Live copepods & Frozen copepods & Fish larvae \\
\hline Crude protein & $56.5 \pm 0.23^{\mathrm{a}}$ & $39.0 \pm 0.69^{\mathrm{e}}$ & $51.3 \pm 0.44^{\mathrm{c}}$ & $41.1 \pm 0.18^{\mathrm{d}}$ & $55.2 \pm 0.13^{\mathrm{b}}$ \\
Crude lipid & $14.5 \pm 0.07^{\mathrm{a}}$ & $9.6 \pm 0.2^{\mathrm{b}}$ & $8.9 \pm 0.14^{\mathrm{b}}$ & $2.7 \pm 0.57^{\mathrm{d}}$ & $7.2 \pm 0.61^{\mathrm{c}}$ \\
Ash & $14.7 \pm 0.17^{\mathrm{d}}$ & $24.4 \pm 0.63^{\mathrm{b}}$ & $19.3 \pm 0.35^{\mathrm{c}}$ & $34.6 \pm 0.38^{\mathrm{a}}$ & $24.7 \pm 0.30^{\mathrm{b}}$ \\
Glycogen & $4.0 \pm 0.22^{\mathrm{c}}$ & $6.4 \pm 0.27^{\mathrm{b}}$ & $6.1 \pm 0.17^{\mathrm{b}}$ & $7.4 \pm 0.16^{\mathrm{a}}$ & \\
\hline
\end{tabular}

Table 2. Ratio of segmental activity of alkaline phosphatase or aminopeptidase $\mathrm{N}$ in brush border membrane related to segmental activity of a cytosolic enzyme, leu-ala peptidase $(X 1000)$. Means \pm SD $(n=4)$ with the same superscript letter are not significantly different $(P<0.05)$

\begin{tabular}{lllllll}
\hline & D 21 & D 23 & D 25 & D 30 & D 35 & D 40 \\
\hline AP/leu-ala & $22.1 \pm 19.5^{\mathrm{b}}$ & $35.2 \pm 10.17^{\mathrm{b}}$ & $108.8 \pm 67.40^{\mathrm{a}}$ & $165.6 \pm 31.53^{\mathrm{a}}$ & $150.0 \pm 31.80^{\mathrm{a}}$ & $148.9 \pm 29.35^{\mathrm{a}}$ \\
N/leu-ala & $15.6 \pm 7.93^{\mathrm{b}}$ & $17.0 \pm 5.18^{\mathrm{b}}$ & $35.1 \pm 16.7^{\mathrm{ab}}$ & $53.2 \pm 7.43^{\mathrm{a}}$ & $48.7 \pm 8.53^{\mathrm{a}}$ & $55.6 \pm 26.6^{\mathrm{a}}$ \\
\hline
\end{tabular}

